\title{
EXAMINING LEARNERS' INTERACTION IN AN OPEN ONLINE COURSE THROUGH THE COMMUNITY OF INQUIRY FRAMEWORK
}

\author{
Mobsen Saadatmand [mohsen.saadatmand@helsinki.fi], Department of Teacher Education, Faculty of \\ Educational Sciences, Siltavuorenpenger 5, P.O. Box 9, 00014 University of Helsinki, Helsinki, Finland, Lars \\ Ublin[lars.ublin@ki.se], Unit for Medical Education, Department of Learning, Informatics, Management and \\ Ethics, Karolinska Institute, Ber₹̨elius väg 3, SE-171 77 Stockholm, Maria Hedberg \\ [maria.hedberg@abu.lu.se],LottaAbjörnsson[lotta.abjornsson@abu.lu.se],Division for HigherEducation \\ Development, Lund University, P.O. Box 117, SE221 00 LUND, Sweden, Maria Kvarnström \\ [maria.kvarnstrom@ki.se],Unit for Medical Education, Department of Learning, Informatics, Management \\ and Ethics, Karolinska Institute, Berzelius väg 3, SE-171 77 Stockholm, Sweden
}

\begin{abstract}
Open online courses are becoming more prevalent at local level and for and professional development objectives. Proper instructional design combined with use of online tools can promote learner interaction in online environments. Using the Community of Inquiry (CoI) framework, this study aimed at examining learners' interaction and their perceptions of teaching presence, social presence, and cognitive presence in an open online course offered for professional development in three Swedish universities. The course was free and open to all, attracting participants from all over the world. In order to understand the online interactions of the course, three presences of CoI were matched to three types of interaction (Moore, 1989). Data were collected through a slightly revised version of the CoI instrument and open-ended questions were added. Survey results showed that participants had high perceptions of the three presences in the course. Results also yielded significant relationships between teaching presence and cognitive presence, as well as social presence and cognitive presence. The findings suggest that deploying a set of online tools combined with appropriate pedagogical approaches in designing open online courses could foster learner interaction especially learner-content interaction and cognitive presence.
\end{abstract}

\section{Abstract in Swedish}

Öppna nätkurser kan anpassas till ett mindre format för ändamålet kompetensutveckling. En genomtänkt kursdesign i kombination med digitala verktyg stödjer samspelet mellan kursdeltagare i en digital lärandemiljö. I denna studie användes Community of Inquiry (CoI) som utgångspunkt för att studera interaktionen mellan kursdeltagare och lärmiljön och dess innehåll i en öppen nätkurs som erbjuds för kompetensutveckling till lärare på tre svenska universitet. Kursen var gratis och öppen för alla och samlade deltagare från hela världen. För att åskådliggöra samspelet i kursen matchades de tre typerna av närvaro i CoI med tre sorters interaktioner mellan kursens aktörer (Moore, 1989). Data samlades in genom en reviderad version av CoI-enkäten med tillägg av öppna frågor. Resultaten visade att deltagarna uppfattade en hög grad av närvaro i alla tre dimensionerna och visade också signifikanta samband mellan pedagogisk och kognitiv närvaro, såväl som mellan social och kognitiv närvaro. Fynden antyder att genomtänkt pedagogisk utformning och användning av digitala verktyg vid design av öppna nätkurser kan främja interaktion, särskilt mellan deltagare och kursinnehåll, och kognitiv närvaro.

Keywords: online learning; community of inquiry; presence, learner interaction; open networked learning; open online course 


\section{Introduction}

Alongside massive open online courses (MOOCs) small-scaled open online courses are becoming more widespread in many disciplines in higher education and continuing institutions around the world. MOOCs represent a novel format of online learning and have ushered in an increased interest in learning experiences and learner interactions taking place in open online learning environments (Kilgore \& Lowenthal, 2015). Learning and interactions in complex online environments pose both advantages and challenges. The current era of open movements, online spaces and networks provide learners with processes of dynamic exchange of information and content. In an open online learning environment a wide range of online applications and social networking sites such as Twitter, Google, blogs and social bookmarking tools are deployed to provide just-in-time and flexible learning opportunities where learners can interact, collaborate, share, communicate and manage learning resources on the go (Lambert \& Fisher, 2013; Rahimi, van den Berg, \& Veen, 2015; Saadatmand \& Kumpulainen, 2014). An appropriate pedagogical design and proper exploitation of social technologies are crucial in fostering the processes of communication and interaction (Siemens, 2012; Skrypnyk, Joksimović, \& Kovanović, 2015).

Su, Bonk, Magjuka, Liu, and Lee (2005) emphasize the importance of interaction in high quality online learning and indicate that previous research reveals that "increased interaction results in increased student course satisfaction and learning outcomes" (p.2). They further point out that empirical analysis of the effectiveness of instructional techniques is lacking and there is a need to understand how instructional design and activities might promote interaction in open online learning environments. Furthermore, Gillani and Eynon (2014), by emphasizing ways learners interact in open online courses, state that empirical research on the realities of interaction that may offer new insight into pedagogical value of open online courses. Presence is a concept that has been used to understand interaction in online learning environments. The Community of Inquiry Framework (Garrison, Anderson, \& Archer, 1999) has enabled researchers in distance education and online learning to investigate online interactions. Arbaugh et al. (2008) suggests that the CoI is a powerful and relevant theoretical framework to examine and explain online learning effectiveness and provides opportunities for researchers to evaluate learners' interaction and experiences in online learning environments. The community of inquiry framework assumes that learning in an online environment happens through interaction of three main elements: teaching presence, social presence, and cognitive presence. The three presences in the CoI framework correspond to three types of interactions (Moore, 1989) i.e., teaching presence to learner-instructor interaction, social presence to learner-learner interaction, and cognitive presence to learner-content interaction (Swan, 2006). Learner interaction has been an important unit of analysis in the context of online learning (Eradze \& Laanpere, 2013) but more research needs to be done to explore these interactions in open online environments from the point of view of participants.

The purpose of this study is to examine learners' perceptions of teaching, social and cognitive presence and their interactions in an open online course. The CoI makes sense as the basis for the research. The course was offered as a professional development opportunity for lecturers and professors as well as for postgraduate students on topics related to implementation of online tools and networking technologies in teaching and learning activities.

\section{Background}

\section{Community of inquiry}

The community of inquiry, grounded in Dewey's notion of practical inquiry, is a theoretical framework to evaluate instructional design, learning experiences and interaction in online and distance education (Garrison, Anderson, \& Archer, 1999). Numerous research studies have been 
conducted to develop, conceptualize, and validate the CoI framework in online learning environments (e.g., Akyol \& Garrison, 2011; Arbaugh et al., 2008; Garrison, Cleveland-Innes, \& Fung, 2010; Garrison \& Arbaugh, 2007; Garrison, 2007; Swan, Garrison, \& Richardson, 2009). The CoI framework has evolved progressively as an instrument that is useful for understanding learning activities and pedagogical design in emerging learning environments such as virtual worlds (Mckerlich et al., 2011) and MOOCs (Skrypnyk et al., 2015; Kilgore \& Lowenthal, 2015). This framework has three interconnected components: teaching presence, social presence, and cognitive presence. Presence in fact is described as "a sense of active participation" and a focus on learner creation and contribution through multi-mediated forms of communications (Mckerlich et al., 2011).

Teaching presence involves the design, facilitation, and direction of collaborative inquiries by instructors to enhance meaningful learning experiences and outcomes; when designing online learning environments, for example, it beneficial to employ teaching presence from beginning to end learning activities and interactions (Anderson, Rourke, Garrison, \& Archer, 2001). Teaching presence in online contexts, however, requires more than mere instructor guidance and support; rather it is about establishing and maintaining relationship with learners to promote meaningful learning (Koseoglu \& Koutropoulos, 2016). Social presence, or engagement as some researchers describe it (Clarà, Kelly, Mauri, \& Danaher, 2015) is the ability of participants to identify and project themselves socially and emotionally in a community (Rourke, Anderson, Garrison, \& Archer, 2001) to communicate purposefully in a trusting environment, and develop personal and affective relationships progressively (Swan et al., 2009). Cognitive presence is defined as the process of construction of meaning through explorations, integration, application and sustained reflection in discourse in a community of inquiry (Garrison, 2007). It "reflects higher-order knowledge acquisition and application" (Garrison et al., 1999; p.7).

Teaching presence in the design phase and organization of the learning environment precedes the other two presences. Skrypnyk et al. (2015) emphasize that in an online environment, teaching presence is instrumental for establishing cognitive presence and facilitation of social interaction in a community of learners. Garrison and Cleveland-Innes (2005) also undergirds the influence of teaching presence on cognitive presence. "Teaching presence is important for the creation and sustainability of a community of inquiry focused on the exploration, integration, and testing of concepts and solutions" (p.135). Accordingly, proper design and organization of course activities and the presence of facilitators throughout the course are essential to facilitate interactions in online environments. Bernard et al. (2009) in their meta-analysis of interactions in distance education indicate that online learning environments should be designed to create conditions that enhance interactions. Their analysis suggest that there are two ways of fostering quality of interactions in online education, instructional design through effective course strategies to enhance interaction and software design through deploying a range of social media tools to promote interactivity and learner engagement in course activities. They further call upon online education researchers to develop and examine instructional design with regards to the incorporation of emerging technologies to enhance interactions (Bernard et al. 2009).

\section{The Col and interactions in online learning environments}

Online learning has transformed in the past decade in terms of pedagogical design, technology deployment, and learners' role in shaping their learning experiences. The pedagogical design of courses delivered through learning management systems (LMS) differs from courses delivered via distributed environments (using social media and online tools). The latter provides learners with an ample of opportunities for engagement and interaction through processes of seeking, sensemaking, creating and sharing content in online platforms (Dabbagh, 2005; Skrypnyk et al., 2015). This also requires facilitators to be constantly involved in and present at different activities in the 
course to amplify, curate, comment and support learners (Siemens, 2010; Skrypnyk et al., 2015). Interaction between learners, instructors and content is presumed to play an integral role in online learning and the current generation of online learning needs to effectively deploy tools and instructional designs to facilitate interactions. Interaction has been discussed a lot in literature on distance education. While some definitions of interaction relate it mainly to human-human and social processes of learning (Bernard et al., 2009), other scholars (e.g., Moore, 1989) extends the definition to other types of interaction. Moore (1989) has defined three types of interaction in distance and online education:

- Learner-instructor interaction (L-I) refers to instructor's efforts in curriculum planning, organizing content and activities, and support and encouragements that stimulate learners' interactions and enhance students' motivation and interest during the course.

- Learner-learner interaction (L-L) is the interaction between one learner and other learners and in groups or communities with or without the presence of instructors.

- Learner-content interaction $(\mathrm{L}-\mathrm{C})$ is the process of intellectually interacting with subject matter that results in construct meaning and change of learner's understanding and cognitive structure.

Moore (1989) further states that it is important for distance educators to plan carefully for all three kinds of interaction considering the potential of new technologies. Seeing that there is a growing trend in offering open online courses in higher education, designing online learning environments to optimize learner interaction by the affordance of emerging technologies is extremely important. Hoven (2006) states, with the ever-increasing range of online tools and internet-based learning resources, there is a need for informed pedagogy in designing learning environments that teachers and course designers should consider when utilizing these materials to foster interaction in online settings.

The CoI considers learning in an online environment as an inquiry process that requires learners to be actively engaged with instructor, other learners and content in order to make meaningful learning. In fact, each presence in the CoI model implies some form of interaction in an online environment, i.e., teaching presence refers to interaction with instructors, social presence refers to interaction with other participants, and cognitive presence refers to interaction with content. Swan $(2001,2006)$ has elaborated on Moore's types of interaction and concluded that these three kinds of interaction correspond to three presences in the CoI model and provide useful lenses for understanding interaction in online environments. This study adapted the CoI model as a theoretical framework to analyse the three types of interaction in the course. Figure 1 provides a process-oriented outline to understand learners' interaction in an online environment. 


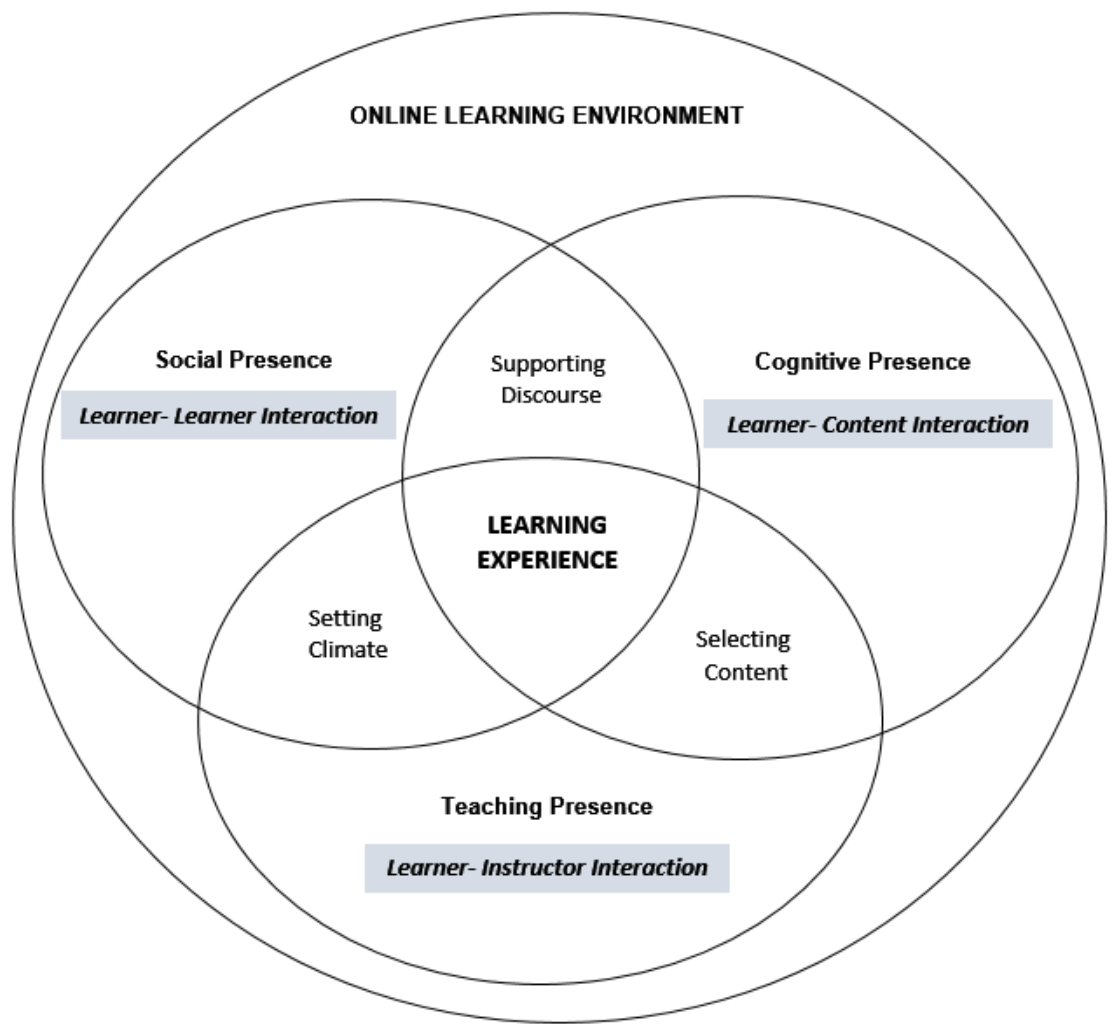

Figure 1. Relationship between interaction and presence in an online environment (adapted from Swan, 2006)

By corresponding teaching presence to learner-instructor interaction (L-I), social presence to learner-learner interaction (L-L), and cognitive presence to learner- content interaction (L-C), this study aimed to investigate participants' perceptions of these three type of interaction in the course. The research questions that guide this study are:

- How do course participants perceive teaching, social, and cognitive presence as they correspond to L-I interaction, L-L interaction, and L-C interaction?

- What relationships exist among teaching, social, and cognitive presence and their constituting categories?

- What is the impact of instructional design and learning environment of the course on learners' interaction?

\section{Methods}

\section{Course description and participants}

The study was conducted in an eight-week open online course titled "Open Networked Learning." It was offered as a professional development course at three Swedish universities: Karolinska Institute, Lund University and Linnaeus University. The primary target group was university teachers, educational technologists, educational developers and course designers but it also attracted educators from other educational sectors both public and private. The course was offered free of charge to all, including out-of-country participants. There were two types of participants in the course: institutional learners from the three partner universities who enrolled as part of their professional development and were required to complete the course assignments to receive a certificate, and open learners who were mainly post-graduate students. They were not required to complete all course tasks but if they wanted to obtain a certificate, they were required 
to participate actively in the course activities and complete the course assignments. The topics of the course comprised digital literacies, collaborative learning and communities, open learning, open educational practices, and designing learning environments. Approximately 140 participants took part in the course. Participants for this study included those who participated and completed the course in autumn 2014 and spring 2015.

A problem-based learning (PBL) approach (Dolmans, de Grave, Wolfhagen, \& van der Vleuten, 2005) was used in the course as the core instructional design to explore course topics and nurture interactions in small groups. Each PBL group consisted of seven to nine learners from different institutions (mixing institutional learners with open learners) each with a facilitator from one of the host universities. There were six PBL groups in the course; each had one facilitator and one co-facilitator who was a previous course participants. The work in the PBL groups was based on a scenario for each of the course topics. In the PBL groups, participants collaborated synchronously and asynchronously to work on the weekly scenario and sharing their results from their inquiry in the main course community (on Google+). Each PBL group had also its community (on Google+) where the group work and discussions occurred. Figure 2 shows an overview of the work in PBL groups.

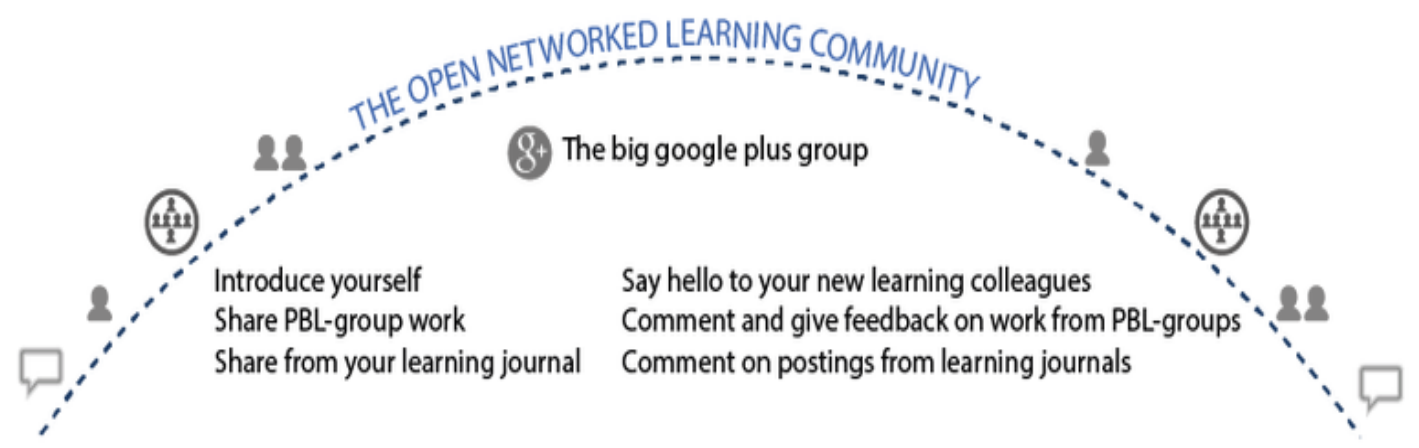

Figure 2. An overview of work in PBL groups

The course instructional design and activities were built to promote learner interaction on several levels as shown in Figure 3. Course activities were designed both synchronously (e.g., weekly webinars, tweet-chat sessions, and small group hangouts) and asynchronously (e.g., interactions in the course community on Google+, commenting on blogs, and tweeting). Facilitating discussion and activities were mediated by active engagement of course facilitators throughout the course by introducing and elaborating on weekly topics and helping participants to get acquainted with course activities and with the environment. In order to foster interaction, a wide range of online tools and social technologies were utilized. They included Google tools (Hangout, Drive, Google+), Twitter, blogging tools (e.g., WordPress, Blogger), social bookmarking (e.g., Diigo), presentation tools e.g., Padlet and Prezi), Wikispaces, and a number of multimedia and visualization tools. On the individual level, blogs were used by course participants to reflect on their learning; and to share their experiences with other participants in the course. 


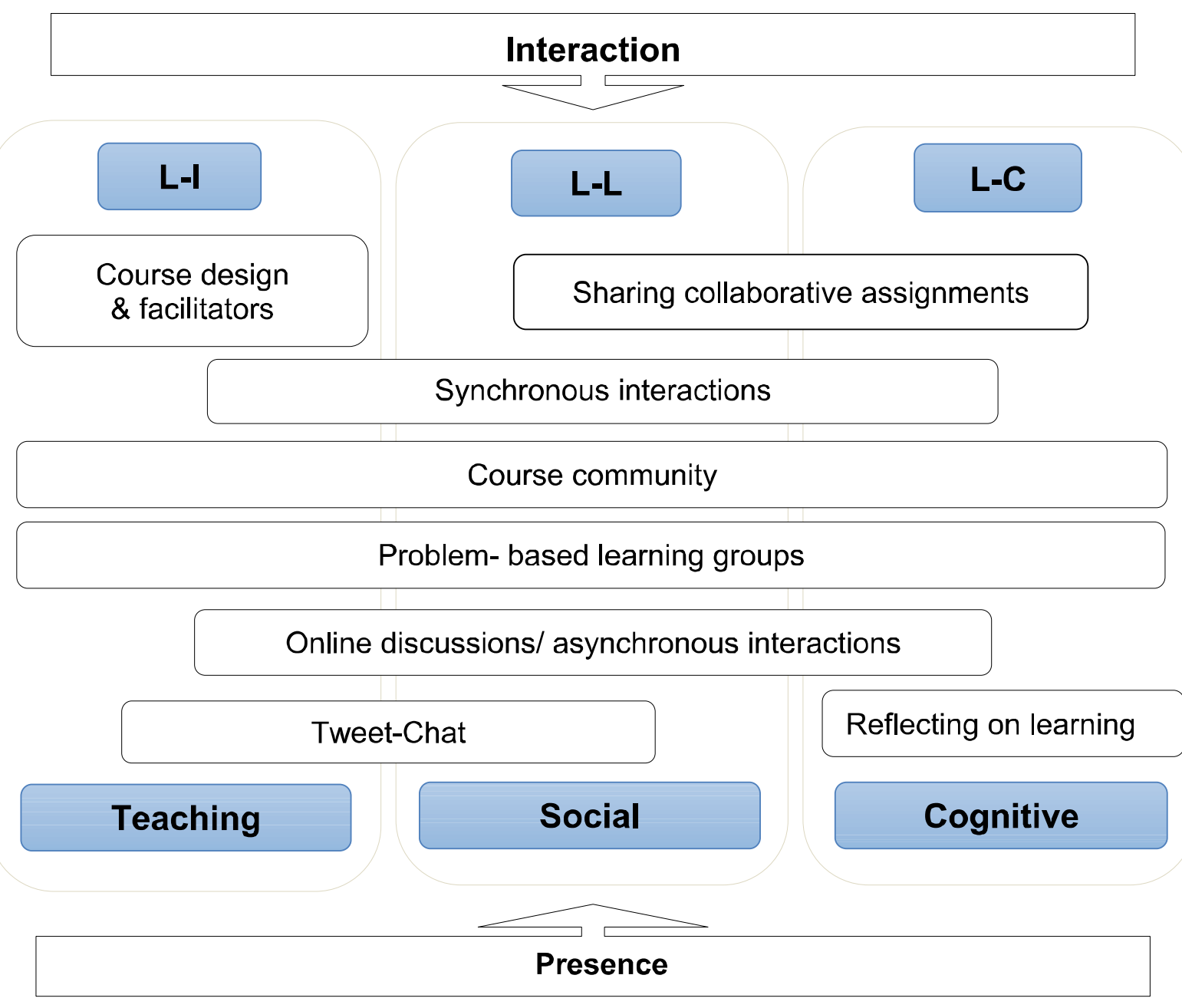

Figure 3. Course instructional design and activities

\section{Data collection and analysis}

Quantitative and qualitative data were used to explore learners' perceptions of presence and their interactions in the course. The CoI survey instrument (Arbaugh et al., 2008) was used as the primary source of data collection. The CoI survey instrument is a valid measure of teaching, social and cognitive presence and it has been used and validated in numerous research in online learning (e.g., Akyol \& Garrison, 2011; Akyol, Vaughan, \& Garrison, 2011; Lambert \& Fisher, 2013; Shea \& Bidjerano, 2010). Each category is comprised of several questions (see Appendix). We slightly modified the CoI survey instrument to best fit our context. In teaching presence under 'design \& organization' section, one more question was added: "Q5: Course online environment and tools supported my learning." In the cognitive presence section, problems was replaced by scenarios in relation to PBL groups' work on weekly scenarios. The modified instrument consisted of 14 items for teaching presence, 9 items for social presence, and 11 items for cognitive presence (see Appendix). Responses were scored using a five-point Likert scale $(1=$ strongly disagree, $2=$ disagree, $3=$ neutral, $4=$ agree, and $5=$ strongly agree $)$. Cronbach's Alpha was 0.88 for teaching presence, 0.86 for social presence, and 0.87 for cognitive presence. For each element of the CoI survey we added one open-ended question to ask participants to write their comments and reflections regarding that section. The responses of these open-ended questions were used as qualitative data to supplement the survey data. The researchers' observations throughout the course were another source of data, which provided remarkable insights to complement and interpret the data and helped to explain, even demonstrate, presence and interaction in the course. 
Table 1: Col survey elements and their categories

\begin{tabular}{ll}
\hline Col Elements & Categories and related questions \\
\hline Teaching Presence & Design \& Organization [Q. 1-5] \\
& Facilitation [Q. 6-11] \\
& Direct instruction [Q. 12-14] \\
Social Presence & Affective Expression [Q. 15-17] \\
& Open communication [Q. 18-20] \\
& Group cohesion [Q. 21-23] \\
Cognitive Presence & Triggering Event [Q. 24-26] \\
& Exploration [Q. 27-28] \\
& Integration [Q. 29-31] \\
& Resolution [Q. 32-34]
\end{tabular}

The survey was built on an online platform (Google Forms). At the end of the course a link to the survey with a consent form was sent to 69 participants who had completed the course. After one month from the initial email request, a reminder was sent. 30 respondents filled in and returned the survey of whom 25 respondents were institutional learners and five respondents were open learners. SPSS was used to analyze the survey data. Descriptive statistics of means were conducted for the survey data. Responses to open ended questions were extracted to a separate document for qualitative content analysis. After conducting the statistical analysis of the survey data, we looked at participants' responses to open ended questions in order to find and interpret how qualitative data correspond to the results from the survey.

\section{Results}

Table 2 shows demographic information of the survey participants. About $73 \%$ of the respondents stated that they did not participate in any online courses or MOOC before.

Table 2: Demographic information of survey respondents

\begin{tabular}{lcc}
\hline & N & Percent \\
\hline Gender & & \\
Male & 13 & $35 \%$ \\
Female & 17 & $65 \%$ \\
\hline Age & 5 & $16.7 \%$ \\
$26-35$ & 12 & $40 \%$ \\
$36-45$ & 13 & $43.3 \%$ \\
\hline 6 and older & & \\
\hline Title & 4 & $13.3 \%$ \\
PhD student & 10 & $33.3 \%$ \\
University lecturer/teacher & 8 & $26.6 \%$ \\
Associate/ professor & 8 & $26.6 \%$ \\
$\quad$ Other & & \\
\hline
\end{tabular}

Table 3 presents the mean scores of the CoI survey elements and constituting categories. The results show that participants had high perceptions of three presences in the course. 
Table 3: Mean scores of the Col survey elements $(N=30)$

\begin{tabular}{lcc}
\hline The Col survey elements & Mean & Std. Deviation \\
\hline Teaching Presence & 4.02 & 0.55 \\
Design \& Organization & 4.12 & 0.68 \\
Facilitation & 4.05 & 0.64 \\
Direct Instruction & 3.78 & 0.71 \\
Social Presence & 4.12 & 0.53 \\
Affective Expression & 4.22 & 0.62 \\
Open Communication & 4.11 & 0.72 \\
Group Cohesion & 4.03 & 0.54 \\
Cognitive Presence & 4.03 & 0.56 \\
Triggering Event & 3.93 & 0.66 \\
Exploration & 4.00 & 0.77 \\
Integration & 4.20 & 0.59 \\
Resolution & 3.98 & 0.76 \\
TOTAL Col & 4.05 & 0.46 \\
\hline
\end{tabular}

Perception of teaching presence achieved a high score $(\mathrm{M}=4.02, \mathrm{~S}=0.55)$ with greater scores in design \& organization and facilitation. For instance responses to Q. 5 about course learning environment yielded a high mean score $(\mathrm{M}=4.10, \mathrm{SD}=0.96)$. Responses from open-ended questions showed positive perceptions of course learning environment. One participant explained it: "the course is in many ways excellently designed but due to my personal work schedule, it has been nearly impossible to keep up the pace with expected course assignments and tight deadlines." Results related to "direct instruction": how course facilitators helped participants keep up with the course activities and assignments, and identify their strengths and weaknesses in the course $r$ showed lower mean scores. Responses from the open-ended questions revealed that some participants found it somehow difficult to fulfil the course requirements and tasks in a weekly tight deadline. For instance, one participant states: "eight hours a week as recommended by course facilitators would be enough but, I spent a bit more than that and still felt stressed with fulfilling in preparing one presentation per week." Facilitation processes including guiding participants towards understanding course topics; keeping them motivated throughout the course were perceived high in the course. One participant describes facilitation as one important factor in being motivated in the course: "The professional and inspirational coaching from the PBLgroup facilitators has without doubt been the most valuable factor for my motivation to carry out the course. The excellent support given from them and course staff, has greatly contributed to my wish to deepen my 'course knowledge' and apply the treated course issues in my own professional context."

Social presence received the highest score $(\mathrm{M}=4.12, \mathrm{SD}=0.53)$. Participants perceived affective expression, which includes a sense of belonging to the course community, being comfortable in expressing themselves, and being engaged in course discussions. For instance responses of Q. 15 (Getting to know other course participants gave me a sense of belonging in the course) yielded a high mean score $(\mathrm{M}=4.37, \mathrm{SD}=0.80)$. We observed that learner-learner interaction and learnerinstructor interaction in the form of synchronous interactions such as webinars and hangouts were perceived as stimulating means of promoting social presence. Interaction through those tools seemed to have helped participants develop a sense of belonging to the course community and engagement with other participants. One participant positively expressed it:

"I think the synchronous activities are very important to creating a sense of belonging for participants and important to the identity of the course: the webinars with the ongoing chat, the hangouts with the discussions and collaboration on a presentation, and the Tweet-chats. 
They create a sense of presence, which enbance reflections and fosters knowledge building/creation."

Another participant expresses a similar experience: "online tools used in the course such as Google+ community, twitter and personal blogs enhanced social interactions among participants. Especially Google+ community was a good place to post about different topics and see other participants' viewpoints and comments or further information on the topics. Tweet-Chat was a new way of quick thinking and reflecting on topics and at the same time interacting with other people." The fact that almost all participants joined the course's Google+ community and most of them were actively engaged in the discussions by posting their questions, comments, and sharing learning diaries supports the importance of community aspect of learning and social interaction.

Cognitive presence received a satisfactory level of perception $(M=4.03, \quad S D=0.56)$. Interestingly, integration received highest mean score $(\mathrm{M}=4.20, \mathrm{SD}=0.59)$ in cognitive presence. This indicates that participants found the course topics and problems relevant to their learning goals and they have been able to connect the ideas and concepts investigated in the course to their practical situations. However, the results showed that participants perceived it to be cognitively challenged and had a sense of confusion and frustration on how to deal with the problems (scenarios) imposed in the course PBL groups. For example Q. 24 (scenarios posed increased my interest in course issues) received the lowest mean score $(\mathrm{M}=3.63, \mathrm{SD}=0.96)$. However, based on our observation, the more participants interacted with course facilitators, the more they became informed on how to work on scenarios and related tasks. Here, the facilitators' role in providing adequate guidance and instructions was very important in directing participants. Working on scenarios in PBL groups seemed to stimulate interaction both among participants $(\mathrm{L}-\mathrm{L})$ and between learner and content $(\mathrm{L}-\mathrm{C})$ while seek information and solutions through different online resources. One participant explains working in PBL groups like this:

"Scenarios in the course were confusing in the beginning. Working in small groups was
somewhat a challenge to do the tasks and labour among PBL group members. Although
working in PBL group was great in a sense that helped to collaborate and develop problem
solving and information seeking skills. For any scenario, it required to think, look, for
relevant information and tools, and combination of different things to produce the final work
for presentation in the course community. It was challenging working on scenarios in PBL
groups but it was a good way to learn how to collaborate and explore different solutions!"

On the other hand, working on scenarios in PBL groups and learner interaction with content through different means prompted an increase in learner-learner interaction in order to collaboratively accomplish the required tasks in the PBL groups. Participants perceived it challenging to keep up with the tight schedule of the course, which do not allow learners to interact adequately with content and accomplish learning tasks. One participant puts it this way: "the premises for a proper course participation has not been satisfactory. Just one week for each topic was not (in my case) sufficient time to gain a deeper knowledge and/or convenience with treated concepts. So extending the course for double the time would let our learning outcomes be more than a 'scratch on the surface"'. The issue here, from an instructional design point of view, is that how to design and organize learning activities and interactions in an online environment in order to optimize both time management and students' meaningful learning and participation in a way that lead to a promote cognitive presence. 


\section{Relationships among teaching, social, and cognitive presence and subcategories}

Pearson's correlation coefficient was conducted to examine relationships among the three presences and their subcategories. The analysis yielded positive significant relationships between teaching presence and cognitive presence $(\mathrm{r}=.67, \mathrm{p}=.000)$ and between social presence and cognitive presence $(\mathrm{r}=.56, \mathrm{p}=.001)$. It indicates that participants who perceived higher level of teaching presence and social presence also perceived higher level of cognitive presence. However, the analysis did not find a significant relationship between teaching presence and social presence $(\mathrm{r}=.31, \mathrm{p}=.093)$.

The significant relationship between teaching presence and cognitive presence can be explained with regard to PBL groups' work on scenarios in the course that participants interacted with course facilitators in order to understand the course topics and problems (scenarios). Especially, the correlation analysis found significant relationships between integration and subcategories of both teaching presence and social presence. These strong relationships indicate the interrelatedness of three presences and how crucial teaching and social presence are for enhancing cognitive presence. Overall, these relationships are indicators that effective interaction between instructors and learners (both facilitation and direct instruction) and interaction among learners while working on scenarios in PBL groups are crucial in meaningful learning and cognitive development of the course topics.

Table 4: Relationships among teaching, social, and cognitive presence and their subcategories

\begin{tabular}{|c|c|c|c|c|c|c|c|c|c|c|c|c|c|}
\hline & 1. & 1.1 & 1.2 & 1.3 & 2. & 2.1 & 2.2 & 2.3 & 3. & 3.1 & 3.2 & 3.3 & 3.4 \\
\hline $\begin{array}{l}\text { 1. Teaching } \\
\text { Presence }\end{array}$ & 1 & $.779 * *$ & $.862 * *$ & $.824^{* *}$ & .312 & .267 & $.371^{*}$ & .123 & $.671^{* *}$ & $.495^{* *}$ & $.471 * *$ & $.595 * *$ & $.619 * *$ \\
\hline 1.1 Design \& & & 1 & $.408 *$ & $.492 * *$ & .286 & .276 & $.369 *$ & .038 & $.400 *$ & $.403 *$ & .169 & $.389 *$ & .325 \\
\hline Organization & & & & & & & & & & & & & \\
\hline 1.2 Facilitation & & & 1 & $.665^{* *}$ & .239 & .169 & .328 & .076 & $.685^{* *}$ & $.469 * *$ & $.532 * *$ & $.565^{* *}$ & $.663 * *$ \\
\hline 1.3 Direct & & & & 1 & .243 & .222 & .164 & .247 & $.553^{* *}$ & .301 & $.477 * *$ & $.516 * *$ & $.525^{* *}$ \\
\hline Instruction & & & & & & & & & & & & & \\
\hline 2. Social Presence & & & & & 1 & $.889 * *$ & $.810 * *$ & $.863^{* *}$ & $.566^{* *}$ & $.404 *$ & $.524 * *$ & $.630 * *$ & .348 \\
\hline 2.1 Affective & & & & & & 1 & $.511^{* *}$ & $.808^{* *}$ & $.452 *$ & $.372 *$ & $.441 *$ & $.557^{* *}$ & .176 \\
\hline Expression & & & & & & & & & & & & & \\
\hline 2.2 Open & & & & & & & 1 & $.475^{* *}$ & $.523 * *$ & .317 & $.386 *$ & $.554^{* *}$ & $.458^{*}$ \\
\hline Communication & & & & & & & & & & & & & \\
\hline 2.3 Group & & & & & & & & 1 & $.461^{*}$ & .347 & $.532 * *$ & $.487^{* *}$ & .215 \\
\hline Cohesion & & & & & & & & & & & & & \\
\hline 3. Cognitive & & & & & & & & & 1 & $.743^{* *}$ & $.837 * *$ & $.853^{* *}$ & $.854^{* *}$ \\
\hline Presence & & & & & & & & & & & & & \\
\hline 3.1 Triggering & & & & & & & & & & 1 & $.457^{*}$ & $.557 * *$ & $.416^{*}$ \\
\hline Event & & & & & & & & & & & & & \\
\hline 3.2 Exploration & & & & & & & & & & & 1 & $.644^{* *}$ & $.710 * *$ \\
\hline 3.3 Integration & & & & & & & & & & & & 1 & $.629 * *$ \\
\hline 3.4 Resolution & & & & & & & & & & & & & 1 \\
\hline
\end{tabular}

\section{Discussion and conclusions}

In an online environment, presence is crucial and serves to indicate the extent to which learners engage and actively participate with the subject matter in learning activities and communities. The survey results demonstrated high scores for the three presences in the CoI which correspondingly indicate that learners had adequate interactions with instructors (L-I), with peers (L-L), and with content (L-C). With high perception of teaching presence, we argue that teaching presence both in the form of organization and facilitation is important in establishing and maintaining social and cognitive presence and perceived to be critical constituents in enhancing cognitive development of the course topics (Garrison et al., 2010). Both quantitative data and responses to open-ended questions confirmed that presence of facilitators to provide comments and guide participants (facilitation \& direct instruction) was perceived as essential in maintaining participants' motivation throughout the course. With regard to the fact that the majority of participants did 
not have previous experience of online courses (more than $70 \%$ ) it was important to provide thorough introduction to the course environment and format. In addition to designing an interactive online course environment (design \& organization), the presence of instructors (facilitation and direct instruction) is crucial to support and provide guidance to learners whenever they need it. Skrypnyk et al. (2015) emphasize that course facilitators in open networked learning environments preserve a high level of influence on the flow of information, which is scaffold by technological affordances. This course utilized a variety of online and collaborative tools, augmented by appropriate theoretical approach such as problem-based learning to promote leaner-instructor interaction, which on the other hand leaded to enhancing learner- content interaction.

Social presence in terms of establishing and developing a sense of belonging to the course community was perceived to be very important in the course. This is in line with what Liu, Gomez, and Yen (2009) found in their study that students with a higher perception of social presence tend to show a higher degree of interaction with other peers. It is important to consider that course facilitators should provide means and triggers in order to promote social presence and learner-learner interaction. We argue that teaching presence in the phase of pre-course design and organization and the facilitating role of instructors is significant in establishing a learning community that trigger learners' interaction during the course. Another point worth mentioning is that while participation in a community is based on establishing a space of trust (Mackness, Mak, \& Williams, 2010), the results showed that it was challenging to raise issues of disagreement towards others' opinions in the community and that it might cause group to fracture. Lambert and Fisher (2013) also found that raising disagreements in a trusted community of inquiry is not easy for the participants. Although, in an online learning community it is optimal to create venues for learners to raise and share their different points of view and controversies while keeping a sense of trust and respect. Here, course facilitators have important roles to mediate discussions and interactions.

With regard to cognitive presence (learner-content interaction), the study found that teaching presence and social presence greatly mediate cognitive presence. The results revealed a number of significant positive relationships between cognitive presence and all subcategories of teaching and social presence (design \& organization, facilitation, open communication, and group cohesion). This reinforces the previous findings on the importance of teaching presence (e.g., Akyol \& Garrison, 2011), and how designing learning environments and facilitating learning activities can enhance cognitive presence in online courses. In order to promote meaningful learning and enhance cognitive development, learning environments and activities should be carefully designed (design and organization) and instructors should be involved in facilitating discussion and interaction (facilitation). The more participants interact with course facilitators about course topics and assignments, and the more they interact and collaboratively work with peers and other learners, the more they can develop deep and meaningful learning. Deep learning occurs when learners try to construct meaning from the ideas generated in the exploratory phase (exploration) and to connect and integrate them (integration). Garrison and Anderson (2001) state that while students often tend to be remaining in the exploration phase, teaching presence is and integrating appropriate technology and pedagogy is essential in moving the process to more-advanced phase cognitive development (integration and resolution). Interestingly, the correlation analysis revealed significant positive relationships between integration and teaching presence and its categories. This indicates that teaching presence in the course has been effectively supported the transition from exploration phase to integration of ideas into solutions. The significant relationships between cognitive presence and social and teaching presence also indicate integrating a PBL approach into the course instructional design triggered both learner-learner interaction and learner- content interaction. 
Interaction (in all three types) is an important factor in the success of online course (Swan, 2006) and could be conveyed via different means in an online learning environment. Sher (2009) points out that effective incorporating technology in designing and delivering online learning can create possibilities for facilitating and enhancing interaction among learners, instructors and content. In order to design a stimulating online learning environment for interaction, proper instructional design mediated by appropriate tools and pedagogical approaches should be implemented. When designing an online learning environment, both asynchronous interactions such as forums, emails, blogs and other forms of communication that can happen across time and location, and synchronous interactions such as webinars, hangouts and Tweet-chat (as designed in this course) should be planned to stimulate interaction (Bernard et al., 2009). As described in the course description, the course online environment can be designed by utilizing a number of activities and appropriate tools to leverage three types of interactions (L-I, L-L, L-C). Anderson (2003) explains that emerging forms of technology provide a variety of alternatives to be deployed for creating content in different forms that can promote learner-content interactivity in educational contexts.

The findings of this study provide implications for optimal design and delivery of online courses. As there is a growing trend in offering open online courses in various subjects in a variety of types of higher education systems, designing online learning environments with regard to the affordances of new technology to optimize online interactions is important. Integrating appropriate technology and pedagogy in designing online learning environment and instructors' instantaneous presence and facilitation throughout the course can foster interaction with other learners and content. For example, in this study we experienced how design and online environment of the course combined with appropriate instructional design (e.g., problem-based learning approach) could foster interactions especially learner-content interaction and cognitive presence. This is what Abrami, Bernard, Bures, Borokhovski, and Tamim (2011) call "guided, focused, and purposeful" designing and using strategies and techniques for interaction beyond whether the opportunities for interaction exist.

\section{Limitations and future research}

The sample size of this study was small and the findings cannot be generalized. Moreover, though we can observe conceptual limitations to the CoI as a framework to investigate interaction, we can be certain that the objects of measurement corresponding to the three types of interaction are worthy of further investigation. Owing to its fluid nature, it is challenging to investigate interaction in open online spaces. Investigating learners' interaction on different platforms that are used in a course needs a combination of methods and procedures. For instance, tracking their interactions by retrieving participants' logs, their comments on each other's posts, and the number of posts can be combined with qualitative methods such as focus group interviews to give a better insight of the patterns of interaction and learners' motivation.

\section{References}

1. Abrami, P. C., Bernard, R. M., Bures, E. M., Borokhovski, E., \& Tamim, R. M. (2011). Interaction in distance education and online learning: using evidence and theory to improve practice. Journal of Computing in Higher Education, 23(2), 82-103. http://doi.org/10.1007/s12528-011-9043-x

2. Akyol, Z., \& Garrison, D. R. (2011). Understanding cognitive presence in an online and blended community of inquiry: Assessing outcomes and processes for deep approaches to learning. British Journal of Educational Technology, 42(2), 233-250. http://doi.org/10.1111/j.1467-8535.2009.01029.x 
3. Akyol, Z., Vaughan, N., \& Garrison, D. R. (2011). The impact of course duration on the development of a community of inquiry. Interactive Learning Environments, 19(3), 231-246. doi:10.1080/10494820902809147

4. Anderson, T. (2003). Getting the Mix Right Again: An Updated and Theoretical Rationale for Interaction. International Review of Research in Open and Distance Learning, 4(2). doi: 10.19173/irrodl.v4i2.149

5. Anderson, T., Rourke, L., Garrison, D. R., \& Archer, W. (2001). Assessing teaching presence in a computer conferencing context. Journal of Asynchronous Learning Network, 5(2), 1-17. Retrieved February 23, 2017, from http://immagic.com/eLibrary/ARCHIVES/GENERAL/ATHAB_CA/Anderson.pdf

6. Arbaugh, J. B., Cleveland-Innes, M., Diaz, S. R., Garrison, D. R., Ice, P., Richardson, J. C., \& Swan, K. P. (2008). Developing a community of inquiry instrument: Testing a measure of the Community of Inquiry framework using a multi-institutional sample. The Internet and Higher Education, 11(3-4), 133-136. http://doi.org/10.1016/j.iheduc.2008.06.003

7. Bernard, R. M., Abrami, P. C., Borokhovski, E., Wade, C. A., Tamim, R. M., Surkes, M. A., \& Bethel, E. C. (2009). A Meta-Analysis of Three Types of Interaction Treatments in Distance Education. Review of Educational Research, 79(3), 1243-1289.

http://doi.org/10.3102/0034654309333844

8. Clarà, M., Kelly, N., Mauri, T., \& Danaher, P. A. (2015). Can massive communities of teachers facilitate collaborative reflection? Fractal design as a possible answer. Asia-Pacific Journal of Teacher Education, 45(1), 86-98. http:// doi.org/10.1080/1359866X.2015.1095280

9. Dabbagh, N. (2005). Pedagogical Models for E-Learning: A Theory-Based Design Framework. International Journal of Technology in Teaching and Learning, 1(1), 25-44. Retrieved February 23, 2017, from http:/ / citeseerx.ist.psu.edu/viewdoc/download?doi=10.1.1.475.4593\&rep=rep1\&type=pdf

10. Dolmans, D. H. J. M., de Grave, W., Wolfhagen, I. H. A. P., \& van der Vleuten, C. P. M. (2005). Problem-based learning: future challenges for educational practice and research. Medical Education, 39(7), 732-41. https://dx.doi.org/10.1111/j.1365-2929.2005.02205.x

11. Eradze, M., \& Laanpere, M. (2013). Analysing Learning Interactions in Digital Learning Ecosystems based on Learning Activity Streams. Paper presented at the European Conference of Educational Research, Istanbul, September 2013.

12. Gillani, N., \& Eynon, R. (2014). Communication patterns in massively open online courses. The Internet and Higher Education, 23, 18-26.

13. Garrison, D. R. (2007). Online community of inquiry review: Social, cognitive, and teaching presence issues. Journal of Asynchronous Learning Networks, 11(1), 61-72.

14. Garrison, D. R., Anderson, T., \& Archer, W. (1999). Critical inquiry in a text-based environment: Computer conferencing in higher education. The Internet and Higher Education, 2(2-3), 87-105. http://doi.org/10.1016/S1096-7516(00)00016-6

15. Garrison, D. R., \& Arbaugh, J. B. (2007). Researching the community of inquiry framework: Review, issues, and future directions. Internet and Higher Education, 10(3), 157-172. http://doi.org/10.1016/j.iheduc.2007.04.001

16. Garrison, D. R., \& Cleveland-Innes, M. (2005). Facilitating Cognitive Presence in Online Learning: Interaction Is Not Enough. American Journal of Distance Education, 19(3), 133-148. http://doi.org/10.1207/s15389286ajde1903_2 
17. Garrison, D. R., Cleveland-Innes, M., \& Fung, T. S. T. (2010). Exploring causal relationships among teaching, cognitive and social presence: Student perceptions of the community of inquiry framework. Internet and Higher Education, 13(1-2), 31-36. http://doi.org/10.1016/j.iheduc.2009.10.002

18. Hoven, D. (2006). Communicating and interacting: An exploration of the changing roles of media in CALL/CMC. CALICO Journal, 23(2), 233-256. Retrieved from http://www.jstor.org/stable/24156246

19. Kilgore, W., \& Lowenthal, P. R. (2015). The Human Element MOOC: An Experiment in Social Presence. In R. D. Wright (Ed.), Establishing an equitable and fair admissions system for an online (pp. 389-407). Hershey, PA: IGI Global.

20. Koseoglu, S., \& Koutropoulos, A. (2016). Teaching Presence in MOOCs: Perspectives and Learning Design Strategies. Paper presented at the $10^{\text {th }}$ International Conference on Networked Learning 2016, Lancaster.

21. Lambert, J. L., \& Fisher, J. L. (2013). Community of inquiry framework: Establishing community in an online course. Journal of Interactive Online Learning, 12(1), 1-16. Retrieved from http://www.ncolr.org/jiol/issues/pdf/12.1.1.pdf

22. Liu, S., Gomez, J., \& Yen, C. (2009). Community college online course retention and final grade: Predictability of social presence. Journal of Interactive Online Learning, 8(2), 165-182. Retrieved from http://online2.sdccd.edu/bblearntrain/2013_2014/Liu_Gomez_Yen_2009.pdf

23. Mackness, J., Mak, S. F. J., \& Williams, R. (2010). The ideals and reality of participating in a MOOC. Proceedings of the Seventh International Conference on Networked Learning, May 3-4, 2010, Aalborg, 266-274. Retrieved from http://www.lancs.ac.uk/fss/organisations/netlc/past/nlc2010/abstracts/Mackness.html

24. Mckerlich, R., Riis, M., Anderson, T., \& Eastman, B. (2011). Student Perceptions of Teaching Presence, Social Presence, and Cognitive Presence in a Virtual World. MERLOT Journal of Online Learning and Teaching, 7(3), 324-336. Retrieved February 23, 2017, from http://jolt.merlot.org/vol7no3/mckerlich_0911.pdf

25. Moore, M. G. (1989). Three types of interaction. American Journal of Distance Education, 3(2), 17. http://dx.doi.org/10.1080/08923648909526659

26. Rahimi, E., van den Berg, J., \& Veen, W. (2015). Facilitating student-driven constructing of learning environments using Web 2.0 personal learning environments. Computers \& Education, 81, 235-246. http://doi.org/10.1016/j.compedu.2014.10.012

27. Rourke, L., Anderson, T., Garrison, D. R., \& Archer, W. (2001). Assessing Social Presence In Asynchronous Text-based Computer Conferencing. International Journal of E-Learning \& Distance Education, 11(4.2), 1-18.

28. Saadatmand, M., \& Kumpulainen, K. (2014). Participants' Perceptions of Learning and Networking in Connectivist MOOCs. MERLOT Journal of Online Learning and Teaching, 10(1), 16-30.

29. Shea, P., \& Bidjerano, T. (2010). Learning presence: Towards a theory of self-efficacy, selfregulation, and the development of a communities of inquiry in online and blended learning environments. Computers \& Education, 55(1), 1721-1731.

30. Sher, A. (2009). Assessing the relationship of student-instructor and student-student interaction to student learning and satisfaction in Web-based Online Learning Environment. 
Journal of Interactive Online Learning, 8(2), 102-120. Retrieved from http://www.ncolr.org/jiol/issues/pdf/8.2.1.pdf

31. Siemens, G. (2010). Teaching in Social and Technological Networks.

32. Siemens, G. (2012, July 25). MOOCs are really a platform. [Blog post] ELEARNSPACE. Retrieved November 2, 2016, from http://www.elearnspace.org/blog/2012/07/25/moocsare-really-a-platform/

33. Skrypnyk, O., Joksimović, S., \& Kovanović, V. (2015). Roles of course facilitators, learners, and technology in the flow of information of a cMOOC. International Review of Research in Online and Distance Learning, 16(3).

34. Su, B., Bonk, C. J., Magjuka, R. J., Liu, X., \& Lee, S. (2005). The Importance of Interaction in Web-Based Education: A Program-level Case Study of Online MBA Courses. Journal of Interactive Online Learning, 4(1), 1-19. Retrieved February 23, 2017, from http://www.ncolr.org/jiol/issues/pdf/4.1.1.pdf

35. Swan, K. (2006). Virtual interaction: Design factors affecting student satisfaction and perceived learning in asynchronous online courses. Distance Education, 22(4), 306-331. http://doi.org/10.1080/0158791010220208

36. Swan, K., Garrison, D. R., \& Richardson, J. C. (2009). A constructivist approach to online learning: The community of inquiry framework. In C. R. Payne (Ed.), Information technology and constructivism in higher education: Progressive learning frameworks (pp. 43-57). http://doi.org/10.4018/978-1-60566-654-9.ch004

\section{Acknowledgments}

The authors would like to thank Prof. Kristiina Kumpulainen and Dr. Marianna Vivitsou for their valuable feedback on earlier versions of the paper; and Dr. Emmanuel Bofah and Dr. Hassanreza Zeinabadi for their assistance in statistical analysis of the survey data. We are grateful to study participants and facilitators of the course. 


\section{Appendix 1. The revised Col survey instrument}

\section{Demographic Questions}

1. What is your gender?

2. What is your age?

3. What is your profession and/or title?

4. Did you participate as an institutional learner or as an open learner?

5. Have you previously participated in other open online courses or MOOCs?

\section{Teaching Presence}

\section{Design \& Organization}

1. Course facilitators clearly communicated the course goals.

2. Course facilitators clearly communicated the important course topics and content.

3. Course facilitators provided clear instructions on how to participate in the course learning activities.

4. Course facilitators clearly communicated important due dates and time frames for learning activities.

5. Course online environment and tools supported my learning.

\section{Facilitation}

1. Course facilitators were helpful in identifying areas of agreement and disagreement on course topics that helped me to learn.

2. Course facilitators were helpful in guiding participants towards understanding course topics in a way that helped me clarify my thinking.

3. Course facilitators helped keep course participants engaged and participating in productive dialogue.

4. Course facilitators helped keep the course participants on task in a way that helped me to learn.

5. Course facilitators encouraged participants to explore new concepts in the course.

6. Course facilitators reinforced the development of a sense of community among participants.

\section{Direct Instruction}

1. Course facilitators helped focus discussion on relevant issues in a way that helped me to learn.

2. Course facilitators provided feedback that helped me understand my strengths and weaknesses.

3. Course facilitators provided guidance and feedback in a timely fashion.

Please add your comments or reflections regarding any questions in this section.

\section{Social Presence}

\section{Affective Expression}

1. Getting to know other course participants gave me a sense of belonging in the course.

2. I was able to express my emotions and opinions to other course participants. 
3. Online tools and web-based communication enhance social interactions.

\section{Open Communication}

1. I felt comfortable conversing through online tools and communities.

2. I felt comfortable participating in the course discussions.

3. I felt comfortable interacting with other course participants.

\section{Group Cohesion}

1. I felt comfortable disagreeing with other course participants while still maintaining a sense of trust.

2. I felt that my point of view was acknowledged by other course participants.

3. Online discussions helped me develop a sense of collaboration.

Please add your comments or reflections regarding any questions in this section.

\section{Cognitive Presence}

\section{Triggering Event}

1. Problems (scenarios) posed increased my interest in course issues.

2. Course activities stimulated my curiosity.

3. I felt motivated to explore content related questions.

\section{Exploration}

1. I utilized a variety of information sources to explore problems posed in the course.

2. Online discussions were valuable in helping me appreciate different perspectives.

\section{Integration}

1. Combining new information helped me answer questions raised in course activities.

2. Learning activities helped me construct explanations/solutions.

3. Reflection on course content and discussions helped me understand main concepts in the course.

\section{Resolution}

1. I can describe ways to test and apply the knowledge created in this course.

2. I have developed solutions to course problems (scenarios) that can be applied in practice.

3. I can apply the knowledge created in this course to my work or professional related activities.

Please add your comments or reflections regarding any questions in this section.

Please write any other comments regarding your participation in this course (online interactions, collaboration, challenges) and feedback or suggestions on the course design and structure.

Scale: $1=$ strongly disagree; $2=$ disagree; $3=$ neutral; $4=$ agree; $5=$ strongly agree 


\section{Appendix 2. Mean scores of Col survey items}

\begin{tabular}{|c|c|c|}
\hline & Mean & SD \\
\hline Teaching Presence & 4.02 & 0.55 \\
\hline 1. Course facilitators clearly communicated the course goals. & 4.00 & 0.91 \\
\hline 2. Course facilitators clearly communicated the important course topics and content. & 4.27 & 0.86 \\
\hline $\begin{array}{l}\text { 3. Course facilitators provided clear instructions on how to participate in the course learning } \\
\text { activities. }\end{array}$ & 3.87 & 1.00 \\
\hline $\begin{array}{l}\text { 4. Course facilitators clearly communicated important due dates and time frames for learning } \\
\text { activities. }\end{array}$ & 4.37 & 0.76 \\
\hline 5. Course online environment and tools supported my learning. & 4.10 & 0.96 \\
\hline $\begin{array}{l}\text { 6. Course facilitators were helpful in identifying areas of agreement and disagreement on } \\
\text { course topics that helped me to learn. }\end{array}$ & 4.00 & 0.87 \\
\hline $\begin{array}{l}\text { 7. Course facilitators were helpful in guiding participants towards understanding course topics } \\
\text { in a way that helped me clarify my thinking. }\end{array}$ & 4.21 & 0.77 \\
\hline $\begin{array}{l}\text { 8. Course facilitators helped keep course participants engaged and participating in productive } \\
\text { dialogue. }\end{array}$ & 4.07 & 0.78 \\
\hline $\begin{array}{l}\text { 9. Course facilitators helped keep the course participants on task in a way that helped me to } \\
\text { learn. }\end{array}$ & 3.93 & 0.86 \\
\hline 10. Course facilitators encouraged participants to explore new concepts in the course. & 4.30 & 0.79 \\
\hline 11. Course facilitators reinforced the development of a sense of community among participants. & 4.10 & 0.81 \\
\hline $\begin{array}{l}\text { 12. Course facilitators helped focus discussion on relevant issues in a way that helped me to } \\
\text { learn. }\end{array}$ & 3.97 & 0.68 \\
\hline $\begin{array}{l}\text { 13. Course facilitators provided feedback that helped me understand my strengths and } \\
\text { weaknesses. }\end{array}$ & 3.53 & 1.00 \\
\hline 14. Course facilitators provided guidance and feedback in a timely fashion. & 4.00 & 0.83 \\
\hline Social Presence & 4.12 & 0.53 \\
\hline 15. Getting to know other course participants gave me a sense of belonging in the course. & 4.37 & 0.80 \\
\hline 16. I was able to express my emotions and opinions to other course participants. & 4.23 & 0.56 \\
\hline 17. Online tools and web-based communication enhance social interactions. & 4.07 & 0.98 \\
\hline 18. I felt comfortable conversing through online tools and communities. & 4.14 & 0.99 \\
\hline 19. I felt comfortable participating in the course discussions. & 4.10 & 0.75 \\
\hline 20. I felt comfortable interacting with other course participants. & 4.23 & 0.77 \\
\hline $\begin{array}{l}\text { 21. I felt comfortable disagreeing with other course participants while still maintaining a sense } \\
\text { of trust. }\end{array}$ & 3.67 & 0.80 \\
\hline 22. I felt that my point of view was acknowledged by other course participants. & 4.27 & 0.52 \\
\hline 23. Online discussions help me develop a sense of collaboration. & 4.17 & 0.79 \\
\hline Cognitive Presence & 4.03 & 0.56 \\
\hline 24. Problems (scenarios) posed increased my interest in course issues. & 3.63 & 0.96 \\
\hline 25. Course activities stimulated my curiosity. & 4.07 & 0.75 \\
\hline 26. I felt motivated to explore content related questions. & 4.23 & 0.67 \\
\hline 27. I utilized a variety of information sources to explore problems posed in the course. & 4.04 & 0.79 \\
\hline 28. Online discussions were valuable in helping me appreciate different perspectives. & 4.23 & 0.67 \\
\hline 29. Combining new information helped me answer questions raised in course activities. & 4.17 & 0.64 \\
\hline 30. Learning activities helped me construct explanations/ solutions. & 4.23 & 0.67 \\
\hline $\begin{array}{l}\text { 31. Reflection on course content and discussions helped me understand main concepts in the } \\
\text { course. }\end{array}$ & 4.20 & 0.80 \\
\hline 32. I can describe ways to test and apply the knowledge created in this course. & 3.97 & 0.77 \\
\hline 33. I have developed solutions to course problems (scenarios) that can be applied in practice. & 3.90 & 0.84 \\
\hline $\begin{array}{l}\text { 34. I can apply the knowledge created in this course to my work or professional-related } \\
\text { activities. }\end{array}$ & 4.23 & 0.85 \\
\hline
\end{tabular}

